\title{
$\AA$ være
}

til

\section{stede}

\author{
Hun har bekledd tre ministerposter og sittet i et utall nasjonale utvalg og råd. Ti år etter nådd \\ pensjonsalder har hun fortsatt et ord med i politikken. Nå er geriateren selv i ferd med å eldes, \\ i alle fall på papiret. Det er tid for å gjøre opp status for et langt liv med mye engasjement.
}

\begin{abstract}
- Du kan tro jeg har hatt en nydelig dag i dag, jeg har sittet og sett på en kobbe som har slått seg til på en liten holme i elven. Der får den ligge i fred nå som laksesesongen er over, forteller Wenche Frogn Sellæg. Jeg er invitert inn i huset hennes som ligger et steinkast fra lakseelven Namsen i Overhalla kommune. Navnet har kommunen fått fra det opprinnelige navnet på et større område i Namdalen, Efri Halfua, som betyr «øvre halvdel». Den ressursrike Namdalen ble i tidligere tider administrativt delt i to. Med sitt rike laksefiske var det naturlig at området rundt Sellæghylla ble sentrum for den øverste halvdelen av dalen. Navnet Sellæg kan du dele i to, sel og lagg, det siste er trøndersk for å ligge. På de små holmene utenfor huset til familien Sellæg har det nok ligget sel i uminnelige tider.
\end{abstract}

Selv om hun har en av Norges flotteste lakseelver som nabo, ble hun aldri bitt av fiskebasillen. Riktignok fikk hun en 13-kilos laks en av de første gangene hun fisket $\mathrm{i}$ elven, men det beskriver hun som ren begynnerflaks. - Jeg har ikke fått annet enn smålaks etter dette. Da jeg fikk laksen på land, ble jeg så redd for å miste den at jeg la meg oppå laksen helt til jeg ble beordret bort slik at noen kunne slå den i hjel, forteller hun lattermildt.

\section{Til dagsordenen}

Det regjeringsoppnevnte prioriteringsutvalget leverte sin innstilling nylig. Innspillene de brakte på banen gjør det fristende å spørre: - Hvilken verdi har et menneskeliv?

- Utvalget reiser en viktig debatt. Skal alder være et indirekte kriterium når helsetjenester skal prioriteres? Etter mitt syn beveger vi oss da inn i en farlig debatt. Vi kan sette diagnoser, prognoser og ressursbruk opp mot hverandre - men er det riktig å sette unge opp mot gamle? Er en 20-årings liv mer verdifullt enn en 70årings om de lider av samme livstruende sykdom? Det er lett å svare ja på dette spørsmålet om man tar utgangspunkt $i$ antatt gjenstående levetid. Men da har vi allerede gjort et valg med dype etiske implikasjoner: et samfunn der eldre mennesker har mindre verdi. Det er alvorlig for hele vår tenking om eldre mennesker.

Livsforlengende behandling for syke gamle er et dilemma vi møter hver eneste dag i helsevesenet. Når utgangen er gitt, er det lindrende, ikke livsforlengende behandling de fleste vil etterspørre. - Og det vil ingen nekte dem, sier hun og fortsetter med

\section{«Jeg er uenig i at geriatrien utelukkende skal være en sykehus- spesialitet»}

stort engasjement: - Men dyre kreftmedisiner som kanskje kan forlenge levetiden med noen måneder, er like vanskelig å gi unge som gamle. Her er vi nødt til å prioritere, ikke mellom aldersgrupper, men om effekt i forhold til ressursbruk. Heller ikke dette er lett, men det vil være nødvendig. Vi kan ikke gjøre alt som er mulig i dag. Men vi kan heller ikke bruke alderskriterier på en måte som gir menneskeliv ulik verdi.

\section{Råd og utvalg}

Wenche tilbringer ikke mye tid langs Namsens bredder. Nå er det ledervervet i Statens seniorråd som krever mest oppmerksomhet. Dette er et regjeringsoppnevnt råd som arbeider uavhengig av partipolitiske skillelinjer. De kan mene hva de vil.

- Vårt mandat er å se på forhold som kan bidra til at eldre står lenger i jobb. Vi vil endre aldersgrensene $i$ arbeidslivet og erstatte alder som kriterium for å inneha autorisasjon som helsepersonell med en sertifiseringsordning. Vi vil at det skal legges til rette for at pensjonister er aktive i samfunnslivet, vi vil være med på å bekjempe aldersdiskriminering. Dette er spennende, slår Wenche fast, tydelig fornøyd med oppdraget. Mens intervjuet skrives legger regjeringen frem et forslag om å øke aldersgrensen for legers rett til å praktisere fra 75 år til 80 år og alle arbeidstakeres rett til å stå i jobb til fylte 72 år. Vi mer enn aner at hun har hatt en finger med i spillet.

- Du har sittet i utallige råd og utvalg til alle tider. Har du ingen grenser for hva du sier ja til?

- Hvis jeg har lyst og tror jeg kan takle oppgaven, klarer jeg sjelden å takke nei til utfordringer som byr seg. Men jeg har alltid sagt nei til å holde 17. mai-taler. Et mindre lydhørt publikum finner du ikke. Her er det unger som blåser høylytt i trompeter og eldre som har klare minner fra krigens dager. Hvordan i all verden skal jeg klare å si noe som treffer alle?

- Jeg har også sagt nei til å lede styret i Helse Midt-Norge. En vanskeligere jobb kan jeg ikke tenke meg. På den ene siden må man lytte til dem som er nær pasientene. På den annen side må man være lojal mot dem som krever innsparinger og effektivisering i sykehusene. Når de økonomiske målene teller mer enn kvaliteten, er jeg glad jeg valgte å si nei til den oppgaven. 12 år i politikken med mange vanskelige valg og sterk personfokusering var nok. Jeg tåler mye uenighet på sak, men når du får negativt fokus på deg som person blir det vanskelig. Da blir det til at man stopper opp og spør seg selv: Er jeg slik? Hvem er jeg egentlig?

- Mediestormer til tross, hva er det som driver deg til å ta på deg så mange oppgaver?

- Jeg har alltid tenkt at jeg må gripe sjansen når den er der, jeg må hoppe på toget når det stopper på stasjonen. Jeg velger 


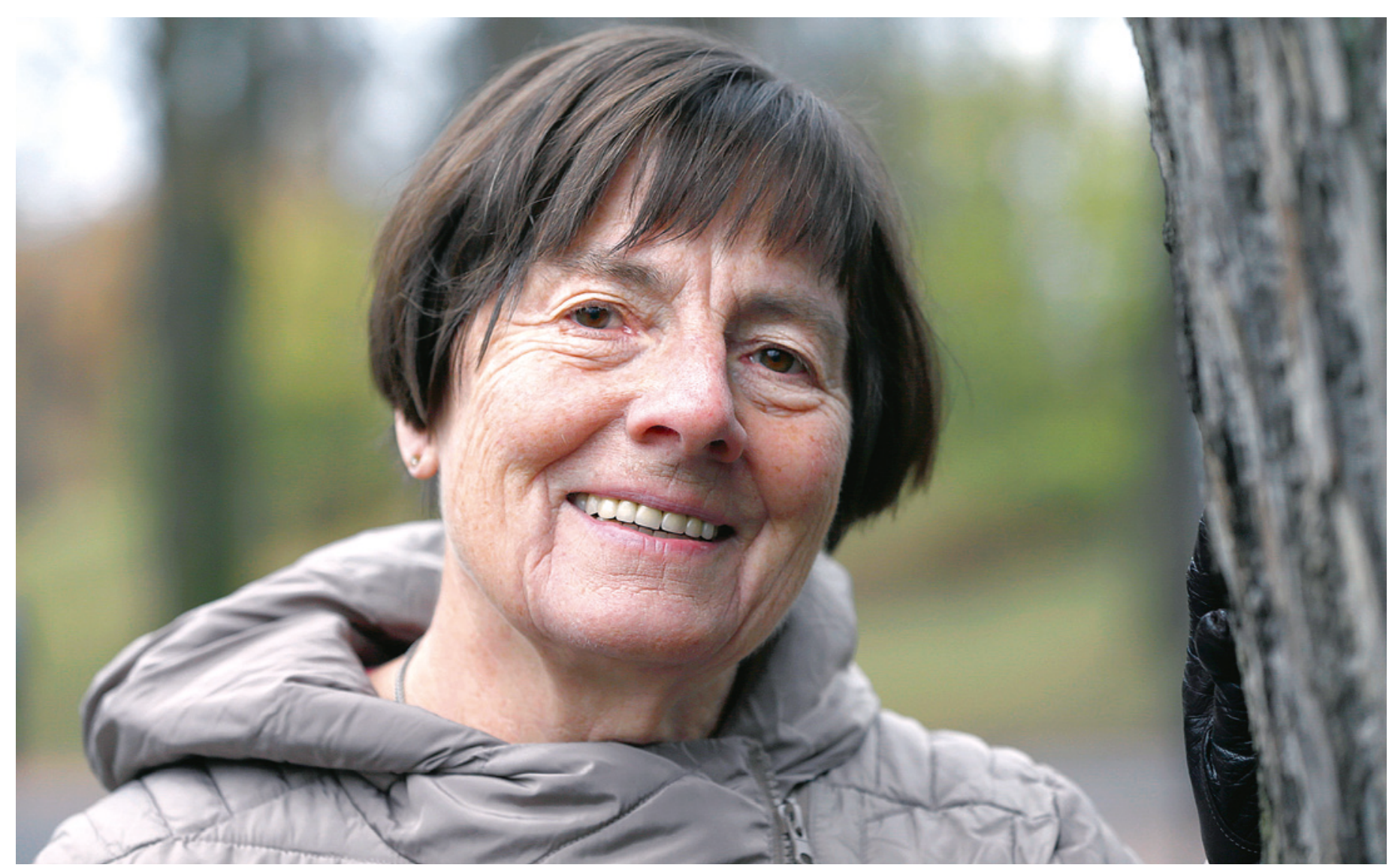

Foto: NTB scanpix

\section{Wenche Frogn Sellæg}

Født 12.8. 1937 i Oslo

- Cand.med. Universitetet i Oslo 1963

- Spesialist i indremedisin 1971

- Spesialist i geriatri 1992

- Master i kunsthistorie 2007

- Lege ved Drammen og Ullevål sykehus 1966-1971

- Misjonslege i Bhutan 1972

- Lege ved Sykehuset Namsos 1973-2007, overlege fra 1975

- Stortingsrepresentant for Høyre 1985-93, vararepresentant 1981-85

- Statsråd i Miljøverndepartementet 1981-83, i Justisdepartementet 1985-86, i Sosialdepartementet 1989-90 å tenke: «Dette klarer du» - selv om jeg ikke har detaljinnsikt i fagområdet. Jeg hadde jo aldri sett et statsbudsjett før jeg gikk inn i regjeringen, humrer hun.

\section{Legekarrieren}

- Tidlig i legelivet valgte du bort videre karriere i Oslo-området. Hvorfor valgte du slik?

- Jeg har alltid vært redd for å bli ensporet. Kvistspesialist ville jeg ikke bli. Jeg ville heller ikke forske, det ble for teoretisk for meg. Etter noen år med sykehusjobber følte jeg behov for å gjøre noe helt annet og valgte å følge en tanke som hadde festet seg mange år tidligere. Da Albert Schweitzer kom til Oslo i 1953 for å motta Nobels fredspris, var jeg blant dem som sto på den tettpakkede Rådhusplassen og hyllet ham. Lederen i Nobelkomiteen talte til folkehavet: - Se på ham, ungdom! Lær av ham! Det ble min marsjordre, sier Sellæg. Hun satte seg et mål om å reise ut som misjonslege.

Tiden for å realisere dette var kommet da hun var ferdig spesialist $i$ indremedisin. Først måtte hun ta et kurs i tropemedisin i London. Der traff hun kolleger fra 40 ulike nasjonaliteter. - Du kan tro det var gøy å være i et så internasjonalt miljø! Alle dro ut etter kurset. Jeg reiste til Bhutan. Misjon var forbudt i landet. Inngangsbilletten var legetittelen.
Men jeg var uforberedt på å skulle bygge opp et helsetilbud fra grunnen av, jeg var ingen pionermisjonær. Jeg mestret det ikke og dro hjem etter et år med mye lærdom i kofferten, ikke minst om meg selv. Dette er en opplevelse jeg ikke ville vært foruten, selv om det var tøft da det sto på.

$\AA ̊$ komme hjem til Oslo ble et sivilisasjonssjokk. Hun mer eller mindre flyktet til Namdalen for å finne seg selv. Her hadde folk mer tid, mer ro, de var mer fornøyde enn i storbyen.

- Jeg er veldig glad for dette valget, jeg har aldri angret på at jeg forlot Oslo-gryta, forteller Wenche, som lar det skinne igjennom at noe av grunnen til at hun er blitt boende i 40 år er lykken i ekteskapet med overhallingen Johan Sellæg.

- Du var gastroenterolog og indremedisiner, men valgte å jobbe i geriatrien. Hva var det med dette faget som fascinerte deg?

- Jeg har alltid ønsket å være nær pasienten $\mathrm{i}$ arbeidet mitt, se helheten. Geriatrien er jo på mange måter allmennmedisin i spesialisthelsetjenesten. Der må man virkelig beherske bredden i faget. Som geriater følte jeg at jeg kunne være ordentlig doktor, bruke hele meg i legejobben. Dessuten har jeg alltid likt å jobbe i team. - Geriatrien som fag har vinglet litt. Skal 
det bli en sykehusspesialitet eller en sykehjemsspesialitet?

- Jeg er uenig i at geriatrien utelukkende skal være en sykehusspesialitet, sier Sellæg. - Da skygger vi for det faktum at de fleste geriatriske pasientene befinner seg i primærhelsetjenesten. Jeg har alltid kjempet for at allmennmedisin skulle bli en inngangsport til geriatrien. Man kunne redusert kravet om sykehustjeneste for dem som ville fortsette å arbeide som geriater utenfor sykehus. Som leder for Geriatrisk forening sloss jeg for dette synet, men nå er slaget tapt. En følge av dette er at sykehjemsmedisinen faller mellom mange stoler.

\section{Politikken}

Rikspolitiker og lege - det blir fristende å spørre om temaer med politisk krutt i seg: - Hvilke tanker har du om samhandlingsreformen?

- Selve ideen om at pasientene først og fremst skal behandles der de bor, er god. Men da må også kommunene få mulighet til å bygge opp tilstrekkelig kompetanse for å mestre oppgaven. Det bekymrer meg at man satte i gang en så stor reform nærmest over natten uten først å vinne erfaring gjennom pilotprosjekter. Rent galt blir det når man nå skal opprette kommunale akuttsenger i sykehjemmene, med begrensede diagnostiske muligheter og manglende døgnkontinuerlig legetilsyn. Hvis det er de eldste som sendes dit, blir det helt feil i mitt hode. Det er jo de gamle som oftest er de mest kompliserte pasientene. Jeg tror dette vil skape en grunnleggende utrygghet i befolkningen. De vil fort oppleve dette som Bsykehus for de gamle.

- Noen steder opprettes forsterkede sykehjem, ofte gjennom interkommunalt samarbeid, fortsetter Sellæg. - Her i Namdalen vil en slik modell svekke et velfungerende lokalsykehus. Taper vi lokalsykehuset, har vi tapt veldig mye.

- Du har engasjert deg sterkt i debatten om eldreomsorgen. Hvor synes du det svikter mest på dette området?

Svaret kommer kontant: - Sykehjemsmedisinen. Jeg tror ikke vi bør beholde sykehjemsinstitusjonene slik de fungerer i dag. Mot slutten av livet vil noen med tunge pleiebehov trenge sykehjemmet som en medisinsk institusjon, men $80 \%$ av dagens sykehjemspasienter har en demenstilstand med behov for helt andre boformer: små oversiktlige enheter som gir pasientene en hjemlig atmosfære og lar dem bruke de ressursene de fortsatt har i behold. Da blir de trygge og beholder selvrespekten lenger. En del er fortsatt motstandere av det som ble kalt boliggjøring av eldreomsorgen. Jeg tror løsningen er rett. Det er mangel på bemanning som har satt den i miskreditt.

\section{Demensforkjemperen}

- Du avsluttet legejobben da du fylte 70 år. Med ditt høye aktivitetsnivå var vel det en stor overgang?

- Nei, den dagen hadde jeg planlagt nøye. Det tror jeg alle bør gjøre, særlig leger som har så mye av identiteten sin knyttet til faget. Jeg har alltid vært interessert i kunsthistorie, og brukte de første årene av pensjonisttilværelsen til å ta en mastergrad. En periode studerte jeg italiensk også for å forstå mer av faget. Men så kom den dagen da masteroppgaven var i havn. Da hadde jeg faktisk ingen planer. Tanken på 20 år som pensjonist uten noe å ta meg til virket langt fra fristende. Jeg vurderte å gå på et doktorgradsarbeid, men så ville Nasjonalforeningen for folkehelse ha meg som leder for Rådet for demens. Den oppgaven har jeg stortrivdes med i mange år - Hvilke saker har du hatt mest oppmerksomhet på her?

- Jeg er svært opptatt av brukermedvirkning. Personer med demens må selv få være med på å bestemme hvilke tjenester og til-

\section{«Jeg er bekymret for den dagen ingen krever noe av meg»}

tak vi skal satse på for å imøtekomme deres behov. Jeg har kjempet for en ny nasjonal demensplan som tar utgangspunkt i dette. Jeg er veldig fornøyd med at helseminister Bent Høye nylig har startet dialogmøter med personer med demens og deres pårørende over hele landet som grunnlaget for en slik plan.

- Hvilke perspektiver bringer de demente inn i arbeidet for demente?

- Det er jo de som er i en tidlig fase av demens som best kan gi uttrykk for sine behov. De forteller oss at de har mer behov for en aktivitetsvenn enn en hjemmesykepleier. De er veldig opptatt av at kunnskapen om demens må spres i hele samfunnet, slik at de kan møte innnsiktsfulle mennesker på bussen, i butikken og andre arenaer det er naturlig å ferdes i. De føler trygghet dersom vanlige folk forstår hvorfor de oppfører seg som de gjør.

Wenche får en egen glød når hun snakker om demensomsorgen. Hun har definitivt ikke lagt sin faglige interesse på hylla selv om det er sju år siden hun fratrådte stillingen som overlege på Sykehuset Namsos.

- Det er to ting jeg mener er tragisk i demensomsorgen, fortsetter hun. - Det ene er at det går flere år fra symptomdebut til diagnosen demens stilles. År med bekym- ring, uro, fortvilelse, ingen hjelp og ingen rettigheter. Det andre som er tragisk er at så mange får dårlig oppfølging etter at diagnosen er satt. I Skottland har regjeringen gitt alle pasienter og deres pårørende en garanti for et års tett oppfølging av en kontaktperson. Her får de tilbud om mer kunnskap, råd av juridisk og sosial art og muligheter til å treffe andre i samme situasjon. Kort sagt: De lærer seg å leve med en sykdom som følger dem resten av livet.

- Men du som selv har vært lenge i politikken, dette vil jo koste mange helsekroner, hvor skal du ta dem fra?

- Det å stille en diagnose avhenger av kompetanse og organisering av utredning. Jeg har ingen tro på det britiske forslaget om å premiere legen med 500 kroner per diagnostisert pasient. På Nasjonalforeningens demenslinje hører vi daglig om pasienter som er sendt ut av kontoret med beskjed om at det er normalt å være glemsk i deres alder. Leger bør klare å skille ut de tidlige symptomene på demens, snakke med de pårørende og iverksette en utredning. Personer med demens og deres pårørende forteller oss at den vanskeligste tiden var før diagnosen ble satt. Dette synes jeg er veldig vondt å tenke på.

- At du fortsatt deltar i utvalg og råd på nasjonalt plan har medført krevende pendling. Du er jo i Oslo hver uke. Det imponerer meg.

- Jo takk, det imponerer faktisk meg også, men jeg opplever ikke at pendlingen tapper meg for krefter, tvert imot. Jeg henter overskudd av det jeg holder på med og at det forventes noe av meg fortsatt. Jeg er bekymret for den dagen ingen krever noe av meg. - Ungdommelig både i sinn og utseende, du merker vel at alderdommen nærmer seg du også?

- Ja, det gjør jeg. Jeg er ikke redd for å bli gammel, men foreløpig holder jeg alderdommen på avstand ved å være mentalt og fysisk aktiv. Jeg har vært veldig heldig med helsa så langt. Jeg synes det er vanskelig å forestille meg en tilværelse der jeg ikke kan gi utrykk for det jeg tenker. Jeg er ikke redd for fysisk forfall, men det ikke å kunne kommunisere, kanskje rett og slett ikke bli sett, det skremmer meg.

- Er du redd for å dø?

- Nei. Det er rart å tenke tilbake på mine unge år, da var jeg livredd for å dø. Det var faktisk et stort problem for meg. Etter hvert merker jeg jo at jeg er litt trett, jeg har opplevd så mye. At det tar slutt en dag, er jo helt naturlig.

\section{Jannike Reymer}

Jannike.reymert@ntebb.no

Bakklandet legekontor

Namsos 